\title{
PENGARUH VARIASI CAMPURAN OKSI-ASETILEN PADA PROSES FLAME HEATING TERHADAP SIFAT FISIS DAN MEKANIK ALUMINIUM SERI 7075
}

\author{
Purnadityanto $^{1}$, Teguh Triyono $^{1}$, Nurul Muhayat ${ }^{1}$ \\ ${ }^{1}$ Teknik Mesin - Universitas Sebelas Maret \\ e-mail addresses : purnadityanto@gmail.com
}

Keywords : Abstract :

Flame heating, Heat treatment aluminum, Aluminum 7075, Impact, Quenching, Aging.
The optimum properties of aluminum can be achieved by the addition of alloy and heat treatment. An experimental study was conducted to investigate the effect of the oxy-acetylene mixture on the flame heating process on the physical and mechanical properties of aluminum 7075. Aluminum was heated to $480^{\circ} \mathrm{C}$ using an oxy-acetylene flame and then cooled rapidly. Then the results were compared with the specimen with flame heating + aging treatment. Variations of oxygen and acetylene mixtures were 0.75, 0.875 and 1 liter/min. The distance of the torch to the specimen's surface is 3 $\mathrm{cm}$ and the water flow rate is $1400 \mathrm{cc} / \mathrm{min}$. The aging process is carried out with a temperature of $120^{\circ} \mathrm{C}$ for 3 hours +165 for 1 hour. The results showed that the highest hardness value in flame heating treatment was 143,10 HVN with acetylene variation 0,875 liter/minute. The result of the impact test does not change much from the initial material toughness value, due to the average flame heating time that is not too long.

\section{PENDAHULUAN}

Aluminium dan aluminium paduan menempati urutan setelah besi dan baja di pasar logam selama lebih dari 70 tahun [1]. Kebutuhan akan aluminium dan aluminium paduan meningkat seiring dengan perkembangan teknologi khususnya pada industri otomotif. Aluminium dan aluminium paduan pada industri otomotif digunakan pada beberapa bagian dan aplikasi antara lain blok mesin, kepala silinder, rumah transmisi, roda gigi, sistem bahan bakar, poros, velg, lengan suspensi, sistem kemudi dan struktur bodi. Dengan bobot ringan dari Aluminium, penghematan berat bagian hingga 50\% dapat dicapai. Inovasi terus dilakukan untuk meningkatkan sifatsifat aluminium.

Sifat optimum dari aluminium dapat dicapai dengan penambahan paduan dan heat treatment. Proses ini mendorong terbentuknya small hard precipitates yang mengganggu gerak dislokasi sehingga meningkatkan sifat mekanik aluminium [1]. Contohnya, aluminium paduan seri 7xxx dengan unsur paduan utama $\mathrm{Zn}$ (seng) $1-8 \%$ dan ketika ditambah dengan persentasi $\mathrm{Mg}$ (magnesium) yang lebih kecil menghasilkan paduan heat treatable dengan kekuatan sedang sampai tinggi [2].

Penguatan aluminium paduan kadang tidak dilakukan pada seluruh bagian komponen mesin. Akan tetapi, penguatan parsial mungkin lebih diinginkan untuk mempertahankan ketangguhan material. Perlakuan panas lokal tersebut diharapkan dapat mengurangi distorsi pendinginan, konsumsi energi dan biaya produksi, serta meningkatkan ketahanan aus dan sifat kelelahan [3].

Pemanasan induksi, laser atau api umumnya digunakan untuk pemanasan lokal. Ketahanan aus dari produk paduan AlSi meningkat dengan surface melting treatment menggunakan laser $\mathrm{CO} 2$. Untuk metode pemanasan induksi, keuletan paduan sheet 1070 aluminium ditingkatkan sebagai akibat dari perlakuan panas lokal dengan menggunakan pemanas induksi. Paduan aluminium 6061 kekerasannya meningkat setelah perlakuan pemanasan induksi [3]. Kekuatan tarik paduan Al$\mathrm{Zn}-\mathrm{Mg}$ meningkat setelah flame rectification [4]. Penelitian tentang perlakuan panas paduan aluminium menggunakan flame heat treatment masih terbatas. Dibandingkan dengan pemanasan laser dan induksi, flame heat treatment lebih mudah pengoperasiannya dan lebih kecil biayanya.

Selama proses flame heating ada parameter yang harus dikontrol, antara lain: temperatur api, waktu flame heating, jarak antara torch dengan permukaan, output energi yang dipasok kepermukaan, tipe material, temperatur material, tipe gas, kondisi ruangan dan tingkat perlakuan yang diinginkan.

Penelitian tentang campuran udara atau gas masih sangat sedikit dilakukan. Sehingga penelitian ini akan membahas tentang pengaruh variasi campuran oksi-asetilen pada pengerasan lokal terhadap sifat fisis dan mekanik Al seri 7075 menggunakan metode flame heating serta fenomena yang terjadi ketika proses berlangsung.

\author{
METODOLOGI PENELITIAN \\ Bahan
}


Bahan yang digunakan pada penelitian ini adalah aluminium paduan (AA 7075). Aluminium seri 7075 memiliki komposisi paduan logam yang

Tabel 1. Komposisi raw material aluminium paduan seri 7075

\begin{tabular}{|l|l|l|l|l|l|l|l|}
\hline $\mathrm{Fe}$ & $\mathrm{Cu}$ & $\mathrm{Mn}$ & $\mathrm{Mg}$ & $\mathrm{Zn}$ & $\mathrm{Ti}$ & $\mathrm{Cr}$ & $\mathrm{Al}$ \\
\hline 0,13 & $1,4-$ & 0,02 & 2,4 & $\begin{array}{l}5,7- \\
5,8\end{array}$ & 0,07 & 0,19 & rem \\
\hline
\end{tabular}

dapat dilihat pada tabel 1. Sebelumnya, aluminium tersebut dilakukan proses pemotongan dan pemesinan untuk dibentuk spesimen pengujian impact dengan standar ASTM E23 dan untuk uji kekerasan mikro.

\section{Proses Penelitian}

Proses awal flame heating dilakukan dengan meletakkan spesimen aluminium 7075 pada backing plate dengan jarak $3 \mathrm{~cm}$ dari permukaan spesimen hingga ujung torch, seperti yang terlihat pada Gambar 1. Kemudian buka katup tabung oksigen dan katup tabung asetilen, serta mengatur tekanan kerja pada regulator oksigen dan asetilen masing-masing sebesar $4 \mathrm{~kg} / \mathrm{cm} 2$ dan $0,4 \mathrm{~kg} / \mathrm{cm} 2$. Selanjutnya buka katup oksigen dan katup asetilen pada torch. Proses flame heating menggunakan variasi campuran oksiasetilen yaitu $0,7: 0,75 ; 0,7: 0,875 ; 0,7: 1$ (Liter/menit) dengan membuka katup pada rotameter.

Selanjutnya perlakuan flame heating diawali dengan memantikkan api pada ujung torch yang telah mengeluarkan campuran gas oksi-asetilen. Selama perlakuan flame heating permukaan benda diukur temperaturnya hingga suhu $480^{\circ} \mathrm{C}$ dan dicatat lama waktu pemanasannya. Setelah temperatur mencapai suhu $480^{\circ} \mathrm{C}$, api kemudian dimatikan dan spesimen didinginkan dengan cepat (quenching) menggunakan air dengan debit $1400 \mathrm{cc} /$ menit dengan waktu pendinginan selama 10 detik.

\section{Pengujian}

Pada penelitian ini dilakukan tiga pengujian yaitu struktur impak, kekerasan, dan struktur mikro. pengujian impact menggunakan standar ASTM E23, dengan metode charpy impact test. Standar ukuran dimensi spesimen uji impact charpy sesuai ASTM E23 ditunjukkan pada Gambar 2.
Pengujian kekerasan yang dilakukan adalah uji mikro vickers. Beban yang digunakan sebesar 100 kgf dengan waktu penekanan selama 15 detik.

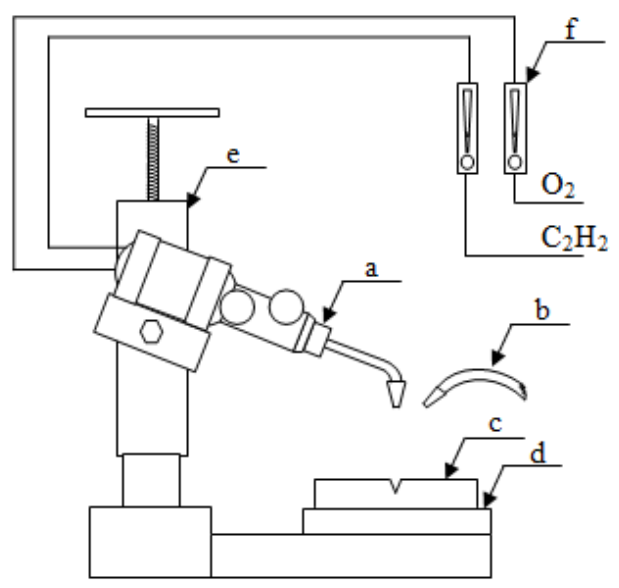

Gambar 1. Skema peralatan flame heating. Keterangan:

a. Torch las gas oksi-asetilen

b. Saluran air

c. Spesimen

d. Backing Plate

e. Pemegang torch

f. Rotamerter udara

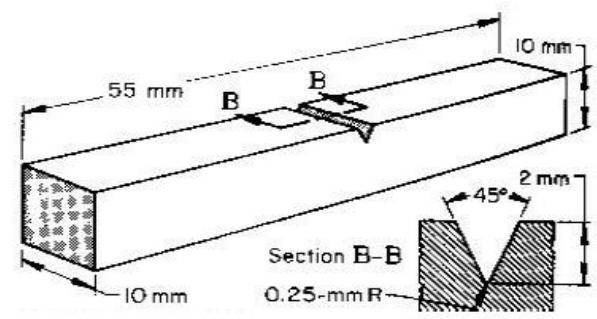

Gambar 2. Dimensi spesimen uji impact charpy (ASTM E23)

Pengukuran kekerasan diukur pada jarak yang berbeda. Masing-masing posisi berada pada tengah spesimen dan arah pengukuran dilakukan dari atas spesimen ke bawah. Jarak yang diambil permukaan yang merupakan titik tepat pada area flame heating, $0,1 \mathrm{~mm}, 0,35 \mathrm{~mm}, 0,60 \mathrm{~mm}$ dan $0,85 \mathrm{~mm}$ seperti yang ditunjukkan pada Gambar 3 .

Pengujian mikro struktur dilakukan dengan melakukan pengamplasan pada bagian permukaan. 


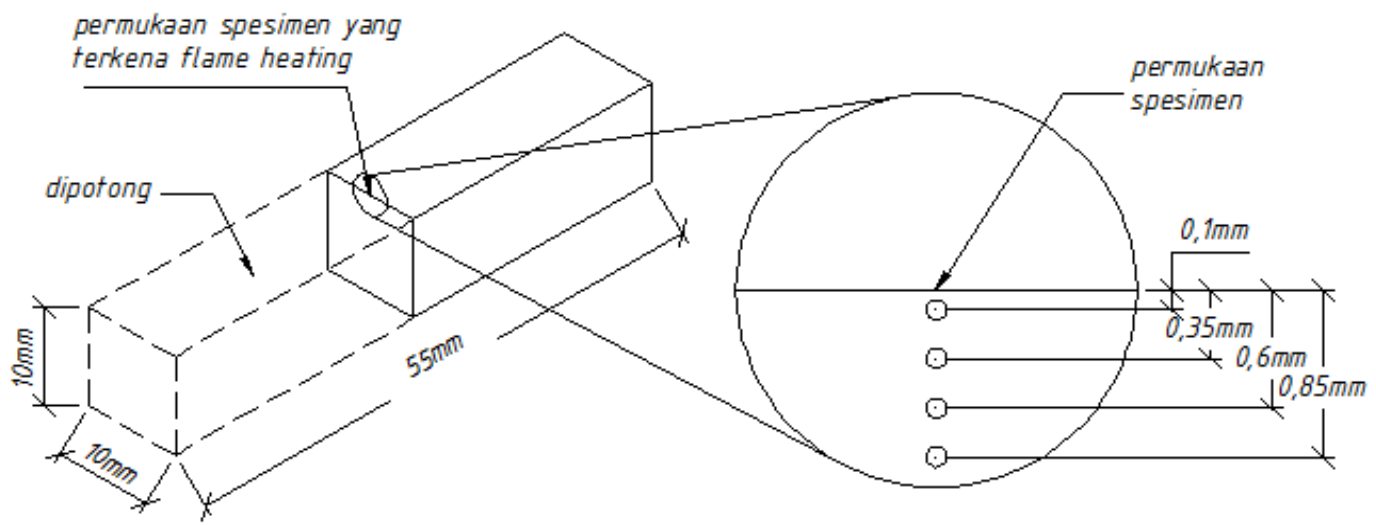

Gambar 3. Skema titik pengujian kekerasan mikro
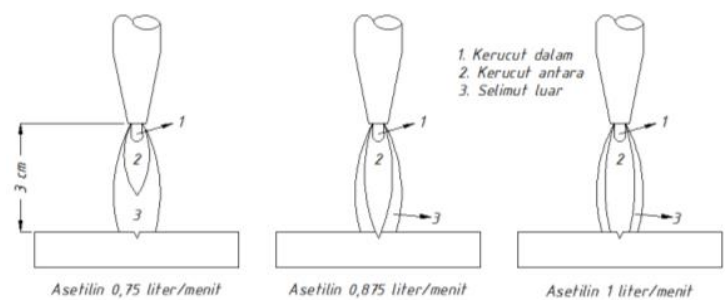

Gambar 4. Ilustrasi nyala api karburasi variasi campuran oksi-asetilin.

vertikal mulai dari pengamplasan kasar 300, 600, 1000, 1200, 1500, dan 2000. Setelah permukaan merata dan halus kemudian dietsa dengan cairan etsa Modified Poulton Reagent $(30 \mathrm{~mL} \mathrm{HCl}, 40 \mathrm{ml}$ HNO3, $2.5 \mathrm{ml} \mathrm{HF}, 42.5 \mathrm{ml} \mathrm{H} 2 \mathrm{O}$, dan 12g CrO3) dan kemudian diamati struktur mikro pada daerah dekat permukaan yang terkena api dan di ambil foto mikronya.

\section{HASIL DAN PEMBAHASAN}

\section{Pengaruh variasi campuran oksi-asetilin} terhadap proses flame heating.

Proses flame heating aluminium hingga suhu $480^{\circ} \mathrm{C}$ dengan jarak antara ujung burner dan permukaan spesimen $3 \mathrm{~cm}$. Variasi campuran oksiasetilin mempengaruhi jenis nyala api karburasi yang terjadi pada ujung burner. Dapat dilihat pada Gambar 4. pada variasi 0,7:0,75 Liter/menit, permukaan benda hanya terkena api selimut luar, yang mana temperatur dari api selimut luar tidak stabil. Pada variasi 0,7:0,875 Liter/menit, permukaan benda terkena ujung api selimut antara. Pada variasi 0,7:1 Liter/menit, permukaan benda juga terkena api selimut antara namun karena pembakaran yang terjadi tidak sempurna, api karburasi pada variasi 0,7:1 Liter/menit menghasilkan jelaga dan menutupi permukaan benda saat proses flame heating berlangsung.

Dengan mencatat lama waktu proses flame heating hingga suhu $480^{\circ} \mathrm{C}$ didapatkan lama waktu rata-rata pada variasi asetilin $0,75 \mathrm{Liter} / \mathrm{menit}$ adalah 4 menit 48 detik, variasi asetilin 0,875 Liter/menit adalah 4 menit 2 detik dan variasi asetilin 1 Liter/menit adalah 5 menit 4 detik. Terjadi perbedaan lama waktu pemanasan yang disebabkan oleh perbedaan nyala api karburasi yang dihasilkan karena variasi campuran oksi-asetilin.

Perlakuan flame heating menyebabkan permukaan aluminium terjadi korosi yang disebut exfoliation corrosion. Gambar 5. memperlihatkan permukaan aluminium setelah perlakuan flame heating. Variasi campuran oksi-asetilin 0,7:0,75 menghasilkan permukaan aluminium yang kasar. Variasi campuran oksi-asetilin 0,7:0,875 menghasilkan permukaan aluminium yang tidak terlalu kasar, namun karena permukaan terkena ujung api antara sehingga ada sedikit cekungan yang terjadi karena panas yang terfokus pada permukaan spesimen. Sedangkan pada variasi campuran oksi-

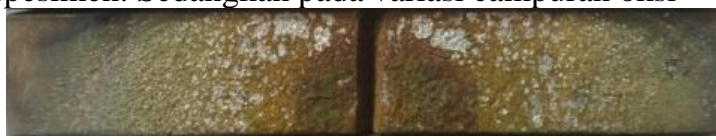

(a)

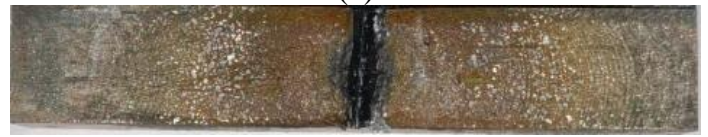

(b)

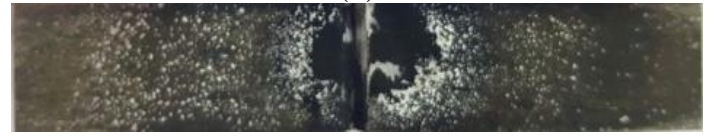

(c)

Gambar 5. Permukaan spesimen setelah flame heating (a) variasi asetilin 0,75 Liter/menit, (b) variasi asetilin $0,875 \mathrm{Liter} / \mathrm{menit}$, (c) variasi asetilin 0,1 Liter/menit.

asetilin 0,7:1 terlihat jelaga pada permukaan aluminium.

Pengaruh Variasi Oksi-asetilin terhadap kekuatan impak.

Pengujian impak dilakukan untuk mengetahui kemampuan suatu material untuk menyerap energi. Hasil pengujian impak charpy yang telah dilakukan diperoleh nilai energi serap dan nilai ketangguhan impak.

Gambar 6. menunjukkan bahwa ketangguhan impak aluminium naik seiring naiknya debit asetilin 
dari material awal. Kenaikannya tidak begitu besar disebabkan karena perbedaan lama waktu rata-rata proses flame heating yang singkat. Nilai rata-rata tertinggi ketangguhan impak sebesar $0,5110 \mathrm{~J} / \mathrm{mm}^{2}$ ditunjukkan pada spesimen dengan debit asetilen 0,875 Liter/menit. Spesimen tersebut mendapatkan nilai ketangguhan yang lebih tinggi daripada spesimen dengan debit asetilen 1 Liter/menit sebesar $0,5065 \mathrm{~J} / \mathrm{mm}^{2}$ dan $0,75 \mathrm{Liter} / \mathrm{menit}$ sebesar 0,4600 $\mathrm{J} / \mathrm{mm}^{2}$. Hal ini disebabkan oleh peningkatan butiran kasar yang mengarah pada peningkatan area batas butir yang meningkatkan jumlah energi yang dibutuhkan untuk pergerakan dislokasi yang diperlukan untuk menyebabkan patahan [1].

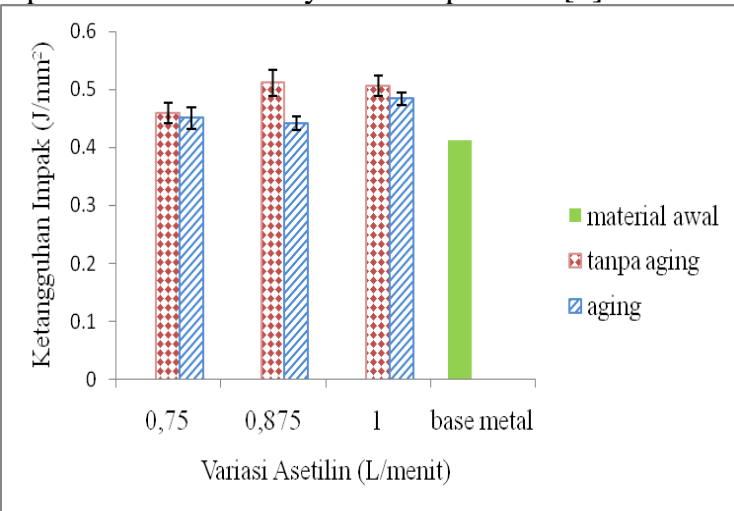

Gambar 6. menunjukkan grafik hubungan antara variasi oksi-asetilin terhadap ketangguhan impak.

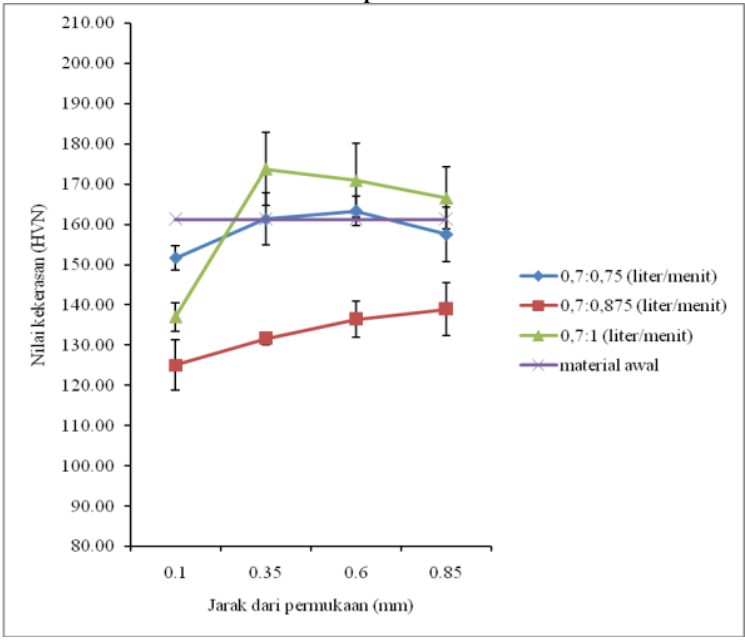

Gambar 7. Grafik nilai kekerasan spesimen aluminium dengan perlakuan flame heating.

Pada spesimen dengan flame heating + aging, nilai ketangguhan mengalami penurunan dari spesimen flame heating. Nilai rata-rata tertinggi ketangguhan impak sebesar 0,4835 $\mathrm{J} / \mathrm{mm}^{2}$ ditunjukkan pada spesimen dengan debit asetilen 1 Liter/menit. Spesimen tersebut mendapatkan nilai ketangguhan yang lebih tinggi daripada spesimen dengan debit asetilen $0,75 \mathrm{Liter} /$ menit sebesar 0,4505 $\mathrm{J} / \mathrm{mm}^{2}$ dan 0,875 Liter/menit sebesar $0,4410 \mathrm{~J} / \mathrm{mm}^{2}$.

\section{Pengaruh Variasi Oksi-asetilin terhadap kekerasan permukaan.}

Kekerasan merupakan ketahanan suatu benda terhadap penetrasi atau gaya tembus dari bahan lain yang lebih keras. Metode pengujian keras menggunakan Hardness Microvickers. Pengujian kekerasan ini dilakukan pada tiap spesimen hasil flame heating dengan variasi campuran oksi-asetilen dengan atau tanpa perlakuan aging. Nilai rata-rata kekerasan pada material awal adalah 161.2 VHN. Gambar 7. dan Gambar 8. menunjukkan grafik nilai kekerasan pada setiap variasi debit asetilen.

Pada Gambar 7. secara umum terlihat bahwa nilai kekerasan permukaan aluminium dengan perlakuan flame heating mengalami penurunan dari nilai kekerasan material awal. Hal ini sesuai dengan teori, jika aluminium mendapatkan perlakuan panas

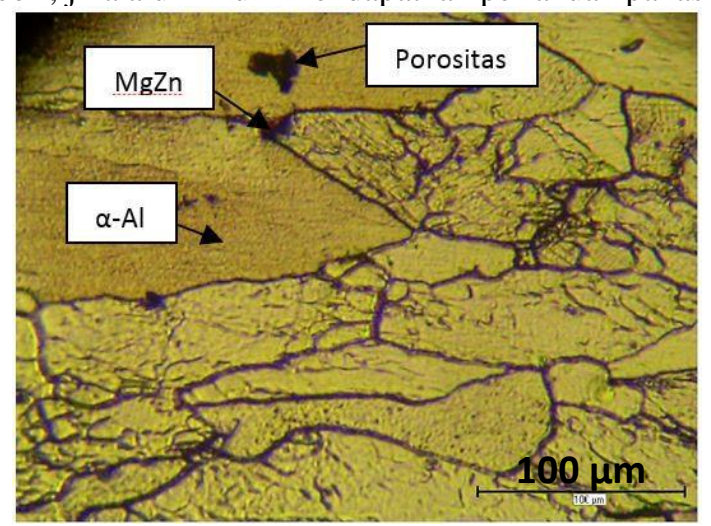

Gambar 9. Foto Struktur Mikro Material awal Al-Zn-

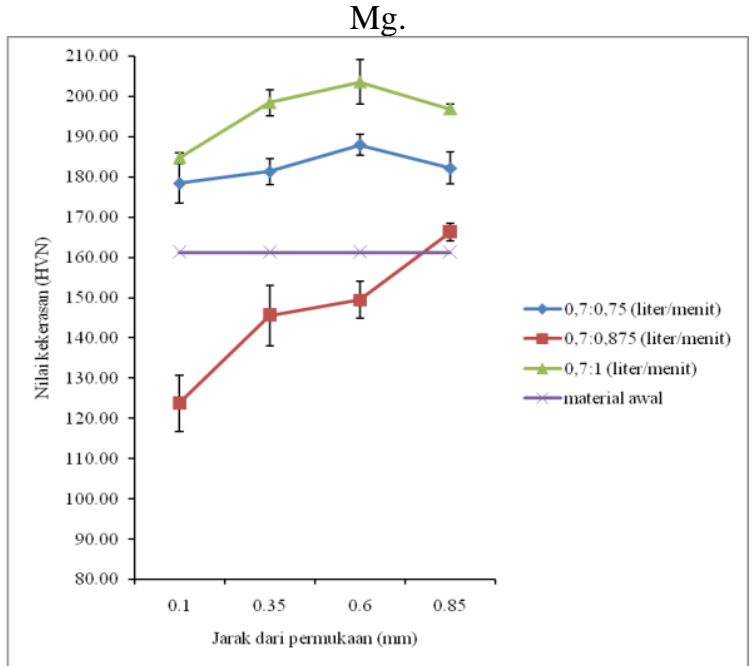

Gambar 8. Grafik nilai kekerasan spesimen aluminium dengan perlakuan flame heating + aging.

hingga menjadi larutan padat dan kemudian didinginkan dengan cepat maka karakteristik aluminium akan melunak, karena tidak ada difusi yang terjadi pada tahap ini. Dengan demikian, fasa yang terbentuk dinamakan Larutan Padat Lewat Jenuh atau Super Saturated Solid Solution. Pada fasa ini unsur $\mathrm{Mg}$ terperangkap pada matriks $\alpha$ dan bersifat sangat lemah. Nilai kekerasan pada jarak $0,1 \mathrm{~mm}$ dengan variasi debit asetilen $0,75 \mathrm{Liter} / \mathrm{menit}$ 
turun menjadi 151,62 HVN, pada variasi debit 0,875 dan 1 Liter/menit nilai kekerasannya menjadi 125,06 HVN dan 136,98 HVN.

Pada Gambar 8. Nilai kekerasan aluminium dengan perlakuan flame heating + aging naik diatas nilai kekerasan material awal pada spesimen dengan variasi asetilen 0,75 dan 1 (Liter/menit). Hal ini sesuai dengan teori bahwa dengan perlakuan aging, kekerasan aluminium dapat meningkat dikarenakan adanya pengendapan presipitat dan ukuran butir menjadi lebih kecil yang dapat dilihat pada Gambar 4.7. foto strukur mikro $d$ dan f. Kekerasan permukaan pada spesimen dengan variasi asetilen 0,875 Liter/menit lebih rendah dari nilai kekerasan material awal namun seiring kedalaman pengujian nilai kekerasannya naik.

Peningkatan nilai kekerasan spesimen yang ditambah perlakuan aging, disebabkan karena selama selama aging, ukuran dan jarak dari matriks endapan meningkat, dengan endapan awal biasanya menjadi koheren, dan kemudian menjadi semi-koheren, dan akhirnya tidak koheren. Perubahan ini menghasilkan peningkatan kekuatan yang terkait dengan fraksi yang meningkat dari presipitat finescale mencapai beberapa distribusi optimal pada kekerasan maksimum [5].

\section{Hasil Pengamatan Struktur Mikro}

Pengamatan struktur mikro dilakukan untuk mengetahui perubahan struktur mikro yang terjadi akibat adanya proses flame heating. Pengamatan struktur mikro pada material awal diambil secara acak pada permukaan spesimen yang telah dietsa menggunakan mikroskop optik. Foto struktur mikro material awal ditunjukkan pada Gambar 9, yang menunjukkan fasa $\alpha$ yang merupakan larutan padat $\alpha$ dalam paduan aluminium,

dengan ukuran butir besar dan persebaran butir tidak merata. Ukuran dan persebaran butir pada material awal terlihat mengalami perubahan pada spesimen dengan perlakuan flame heating + quenching dan flame heating + quenching + aging, yang ditunjukkan pada Gambar 10 Ukuran dan persebaran butir pada spesimen dengan perlakuan flame heating + quenching ditunjukkan dengan notasi a, b dan c. Terlihat ukuran butir pada spesimen dengan perlakuan flame heating + quenching lebih besar dari ukuran butir material awal. Spesimen dengan perlakuan flame heating + quenching + aging ditunjukkan dengan notasi d,e dan $\mathrm{f}$, dengan ukuran butir yang lebih kecil.

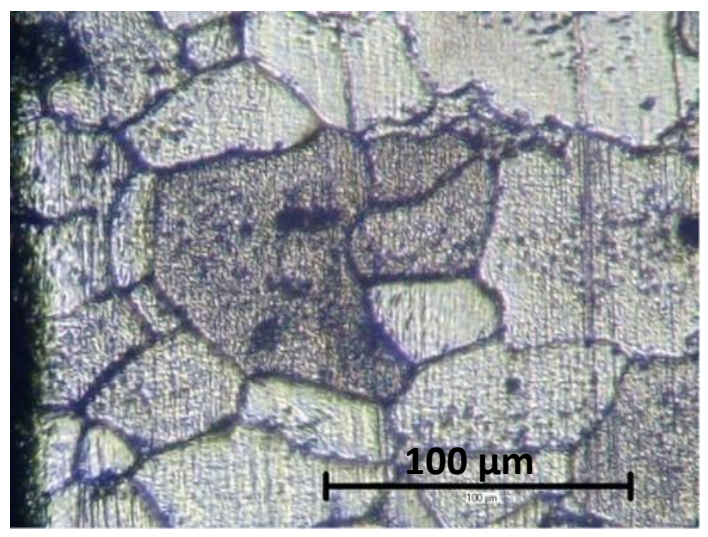

(a)

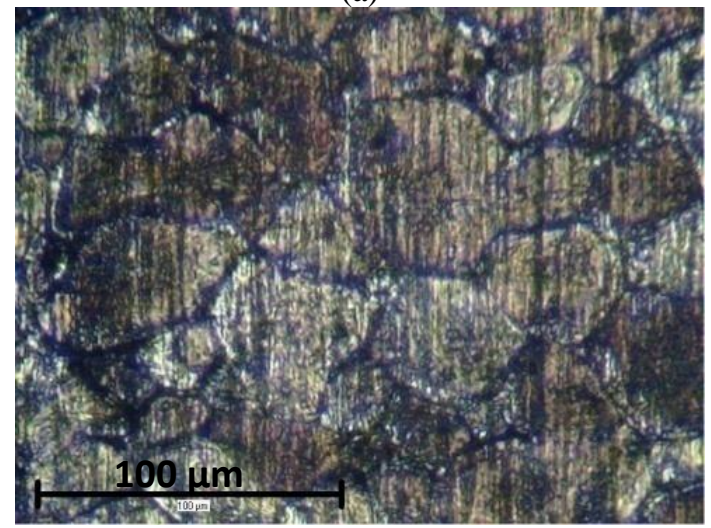

(b)

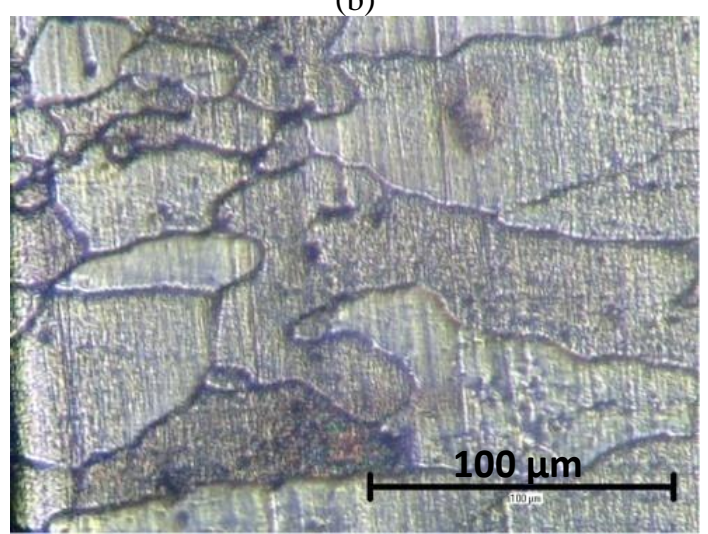

(c)

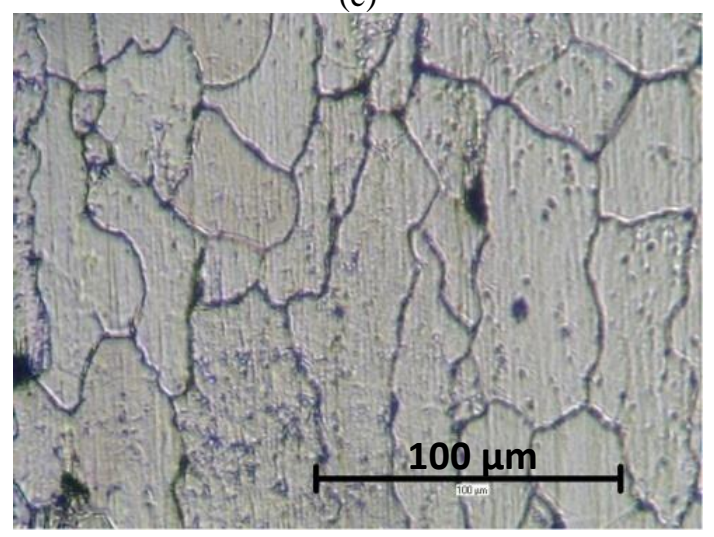

(d) 
Mekanika: Majalah Ilmiah Mekanika 54
Volume 18 Nomor 2 September 2019

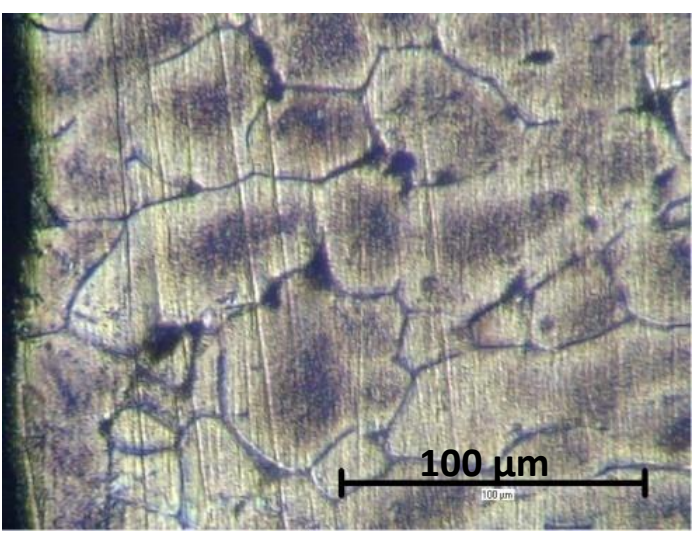

(e)

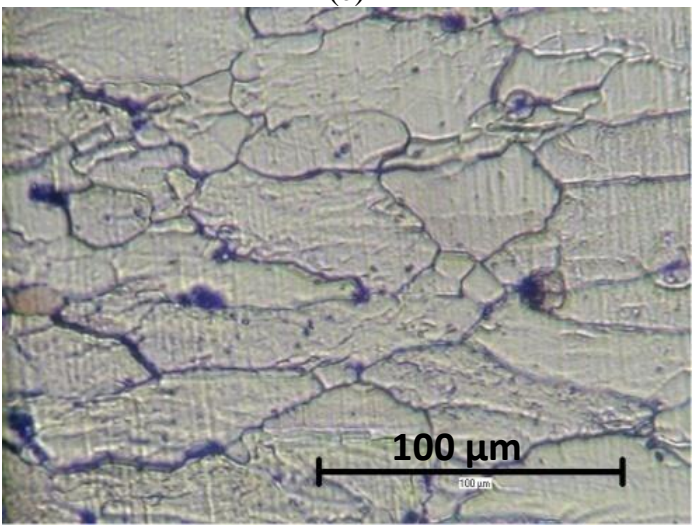

(F)

Gambar 4.7. (a) (b) (c) Foto struktur mikro aluminium dengan perlakuan flame heating + quenching dan (d) (e) (f) dengan perlakuan flame heating + quenching + aging dengan variasi debit asetilen 0,$75 ; 0,875$ dan 1 Liter/menit.

\section{KESIMPULAN}

Berdasarkan hasil pengujian dan pembahasan yang telah dilakukan, maka dapat ditarik kesimpulan sebagai berikut :

1. Nilai ketangguhan impak pada setiap variasi campuran oksi-asetilen memiliki nilai ketangguhan yang berbeda. Setelah dilakukan uji impak pada spesimen aluminium yang telah diproses flame heating dengan debit asetilen 0,875 Liter/menit, nilai ketangguhan impaknya $0,5110 \mathrm{~J} / \mathrm{mm}^{2}$. Kemudian untuk debit asetilen 1 Liter/menit nilai ketangguhan impaknya $0,5065 \mathrm{~J} / \mathrm{mm}^{2}$ dan pada debit asetilen 0,75 Liter/menit memiliki nilai ketangguhan impak paling rendah senilai $0,4600 \mathrm{~J} / \mathrm{mm}^{2}$. Perbedaan nilai ketangguhan impak antara variasi campuran oksi-asetilen tidak terlalu besar, dikarenakan perbedaan lama waktu proses flame heating untuk mencapai temperatur $480^{\circ} \mathrm{C}$ relatif sama.

2. Nilai kekerasan vickers pada permukaan spesimen dengan perlakuan flame heating + quenching mengalami penurunan dibawah nilai kekerasan material awal. Spesimen aluminium yang telah diproses flame heating dengan debit asetilen 0,75 Liter/menit, nilai kekerasannya 151,62 HVN. Kemudian untuk debit asetilen 1 Liter/menit nilai kekerasannya 136,98 HVN dan pada debit asetilen 0,75 Liter/menit memiliki nilai kekerasannya paling rendah senilai $125,06 \mathrm{HVN}$.

\section{DAFTAR PUSTAKA}

[1] A. D. Isadare, B. Aremo, M. O. Adeoye, O. J. Olawale, and M. D. Shittu, "Effect of heat treatment on some mechanical properties of 7075 aluminium alloy," Mater. Res., vol. 16, no. 1, pp. 190-194, 2013.

[2] ASM Handbook, "Volume 2, Properties and selection nonferrous alloys and specialpurpose materials," ASM International, 1990.

[3] F. Shang, E. Sekiya, and Y. Nakayama, "Local reinforcement of 6061 aluminum alloy bar using high-frequency induction heating apparatus," J. Japan Inst. Light Met., vol. 62, no. 10, pp. 377-382, 2012.

[4] H. Lu, L. Shi, H. Dong, S. Li, D. Guo, and C. Tao, "Influence of flame rectification on mechanical properties of [Formula presented] alloy," J. Alloys Compd., vol. 689, pp. 278-286, 2016.

[5] P. A. Rometsch, Y. Zhang, and S. Knight, "Heat treatment of 7xxx series aluminium alloys - Some recent developments," Trans. Nonferrous Met. Soc. China (English Ed., vol. 24, no. 7, pp. 2003-2017, 2014. 